license

\title{
Fenomena Konstruksi Politik Dinasti pada Pilkada Serentak Tahun 2020 di Kabupaten Batang Hari
}

\author{
Hatta Abdi Muhammad ${ }^{1}$, Dony Anggara ${ }^{2}$ \\ hattaabdimuhammad@gmail.com; donyanggara29@gmail.com \\ ${ }^{1}$ Program Studi Ilmu Politik, Universitas Jambi \\ ${ }^{2}$ Program Studi Ilmu Politik, Universitas Jambi \\ DOI: $10.22219 /$ sospol.v7i2.15160
}

\begin{abstract}
This study focuses on examining the phenomenon of dynastic political construction in Batang Hari, especially at the momentum of the 2020 simultaneous regional elections. There are efforts to perpetuate the power of two political elite figures through their representation with the pattern of political kinship. Descriptive qualitative method is used to analyze in depth the phenomena that occur by utilizing secondary data and primary data from various informants. Various data were analyzed interactively and their validity was confirmed and then presented analitical descriptive. The results showed that the dynasty construction in Batang Hari Regency was easily formed not only due to economic factors but also due to the characteristics of the community that were still traditional. The apprehensive socio-economic condition of the community for approximately 20 years indirectly supports the perpetuation of political localization. During this period, it had an impact on the formation of a pragmatic political culture in society. Matters related to rationality (vision and mission, work programs, development) in choosing are forced to be neglected due to socio-economic conditions that make people prefer practical things (money politics) that can meet their needs directly.
\end{abstract}

\section{Abstrak}

Tulisan ini berfokus mengkaji fenomena konstruksi politik dinasti di Batang Hari, khususnya pada momentum Pilkada serentak tahun 2020. Terdapat upaya pelanggengan kekuasaan dari dua tokoh elit politik melalui representasi mereka dengan pola kekerabatan politik. Metode deskriptif kualitatif digunakan untuk menganalisis secara mendalam terhadap fenomena yang terjadi dengan memanfaatkan data sekunder dan data primer dari berbagai informan. Berbagai data dianalisis secara interaktif dan dikonfirmasi keabsahannya kemudian disajikan secara analisis deskriptif. Hasil penelitian menunjukan bahwa konstruksi politik dinasti di Kabupaten Batang Hari mudah terbentuk bukan saja disebabkan faktor ekonomi namun juga disebabkan karakteristik masyarakat yang masih tradisional. Keadaan sosial ekonomi masyarakat yang memperihatinkan selama kurang lebih 20 tahun secara tidak langsung mendukung kelanggengan pelokalan politik. Dalam kurun waktu tersebut berdampak pada terbentuknya budaya politik masyarakat yang pragmatis. Halhal yang menyangkut rasionalitas (visi misi, program kerja, pembangunan) dalam memilih dipaksa diabaikan karena kondisi sosial ekonomi sehingga menjadikan masyarakat lebih menyukai hal-hal yang praktis (politik uang) yang dapat memenuhi kebutuhan mereka secara langsung.

\author{
Keywords \\ Kabupaten Batang Hari, Perilaku \\ Pemilih, Pilkada Serentak, Politik \\ Dinasti
}

\section{Article History}

Received March 12, 2021

Revised June 6, 2021

Accepted November 10, 2021

Published November 16, 2021

\section{Corresponding Author}

Hatta Abdi Muhammad. Jl. Kemas Somad Lorong Masjid No. 90A, Kelurahan Kenali Besar, Kecamatan Alam Barajo, Kota Jambi. 36361. 
license

\section{Pendahuluan}

Pasca berakhirnya pemerintahan Soeharto pada 1998, sistem politik Indonesia bertransformasi dari rezim sentralistik otoriter menjadi pemerintahan yang sentralistik demokratis. Kunci utama proses desentralisasi di Indonesia di landasi oleh Undang-Undang Nomor 22 Tahun 1999 tentang Pemerintahan Daerah yang menstimulus percepatan pengimplementasian desentralisasi dimana pada akhirnya transfer politik, kekuasaan finansial dan administrasi merupakan tanggung jawab pemerintah daerah, kemudian di jelaskan kembali mengenai regulasi terbaru dalam Undang-Undang Nomor 23 Tahun 2014 tentang kepala daerah sebagai unsur penyelenggara Pemerintahan Daerah yang memimpin pelaksanaan urusan pemerintahan yang menjadi kewenangan daerah otonom (Hamid, 2015).

Desentralisasi kemudian menghasilkan sebuah produk Pemilihan Kepala Daerah (Pilkada) secara langsung dilakukan pertama kali pada tahun 2005 yang menjadi sarana bagi masyarakat untuk memilih pemimpin di daerah dimana mereka tinggal tanpa adanya intervensi dari pemerintah pusat sebagaimana sebelumnya pemilihan kepala daerah yang dilaksanakan oleh segelintir elit partai politik lewat lembaga DPRD. Pilkada langsung merupakan kerangka kelembagaan baru dalam rangka mewujudkan proses demokratisasi di daerah. Proses ini diharapkan bisa mereduksi secara luas adanya pembajakan kekuasaan yang dilakukan oleh partai politik yang memiliki kursi di DPRD (Hanafi, 2014). Pada awalnya, Pilkada langsung diharapkan dapat menjadi tonggak demokratisasi masyarakat ditingkat grass root serta peningkatan kesadaran partisipasi politik untuk menentukan masa depan daerah mereka sehingga stabilitas politik bisa tercapai.

Pilkada langsung yang diharapkan tidak ada lagi intervensi dari pihak manapun ternyata pada faktanya masih terjadi fenomena penetapan pasangan calon kepala daerah oleh elit partai politik di tingkat pusat, sehingga yang terjadi adalah hasil dari penunjukan tersebut cenderung oligarkis. Senada dengan Hanafi, pada praktiknya kuasa partai politik tersebut kerap menuai kritik publik. Diantaranya, proses pengusungan kandidat kerap terlihat elitis, rekrutmen calon yang buruk, semaraknya isu mengenai keharusan menyediakan uang sebagai mahar politik oleh kandidat agar memperoleh tiket pencalonan dari partai politik, abainya partai politik pada suara publik terhadap persoalan yang menyangkut politik dinasti di daerah, sampai bagaimana partai politik bisa bekerja dalam mengawal pengusungan kandidat sebagai sebuah mesin politik yang efektif agar tidak sekedar menjadi pemberi tiket.

Berdasarkan pola seperti yang dijelaskan oleh Hanafi diatas, pada akhirnya menempatkan calon kandidat yang tidak memiliki jumlah kapital besar dan privilege secara otomatis akan tersingkir. Sedangkan calon kandidat yang mempunyai modal kapital dalam jumlah besar serta privilege bisa dengan mudah untuk dicalonkan. Sehingga fenomena yang terjadi saat ini banyak kepala daerah yang berasal dari golongan elit dan juga kepala daerah yang kembali mencalonkan diri sebagai incumbent untuk memenuhi batasan dua periode jabatan. Setidaknya terdapat 290 calon kepala daerah petahana yang maju kembali di 236 daerah (CNN Indonesia, 2020) Sebagaimana Dal Bó et al, dalam temuannya bahwa lamanya jabatan berkuasa cenderung memungkinkan seseorang untuk memulai atau melanjutkan kekerabatan Politik (Dal Bó et al., 2009).

Lamanya berkuasa kemudian berimplikasi kepada orientasi sebagaimana Beny Geys dan Daniel M. Smith menjelaskan bahwa elit mungkin ingin mempertahankan cengkeraman keluarga 
yang erat pada jabatan politik, terutama jika keuntungan pribadi dari jabatan melebihi apa yang dapat diperoleh di luar politik. Secara lebih umum, kekayaan, pendidikan, dan koneksi yang dinikmati dalam keluarga elit terkemuka dapat membantu mereka mempertahankan cengkeraman kekuasaan, bahkan ketika dihadapkan pada persaingan elektoral (Geys \& Smith, 2017). Sebagaimana yang ditunjukkan oleh Dal Bó, bahwa legislator yang menjabat untuk beberapa masa jabatan meningkatkan kemungkinan bahwa kerabat mereka dipilih untuk jabatan yang sama di masa depan. Ini sebagian karena modal politik, seperti pengakuan nama dan hubungan dengan mesin politik, dapat diwarisi dalam keluarga (Dal Bó et al., 2009).

Brian D. Feinstein menemukan bahwa keunggulan sumber daya yang dimiliki oleh anggota dinasti memberi mereka keunggulan elektoral yang substansial dibandingkan kandidat lainnya (Feinstein, 2010). Fenomena kekerabatan politik dinilai berpotensi menghambat jalannya sirkulasi politik yang terbuka dan partisipatif (Prianto, 2016). Sehingga menjadi hal yang wajar apabila kekuasaan politik di tingkat lokal seolah menjadi warisan turun temurun oleh elit lokal kemudian menjadi sebuah kekerabatan politik atau istilah Dal Bó et al disebut "kekuasaan akan melahirkan kekuasaan" (Dal Bó et al., 2009).

Sebagai pisau analisa dalam artikel ini, Timothy Besley dan Marta Reynal Querol mengklasifikasikan Politik Dinasti adalah apabila seorang pemimpin tersebut memiliki koneksi dengan keluarga yang pernah memegang posisi politik apapun (ayah, ibu, kakek, paman, saudara laki-laki, sepupu, ipar dan lain-lain)(Besley \& Reynal-Querol, 2013). Pablo Querubin melihat politik dinasti sebagai satu atau jumlah kecil keluarga yang mendominasi distribusi kekuasaan di wilayah geografis tertentu (Querubin, 2013). Disisi lain, Yoes C. Kenawas dalam kajiannya menjelaskan politik dinasti diartikan sebagai pejabat publik terpilih (Gubernur / Walikota / Bupati / Legislator) yang memiliki hubungan kekeluargaan dengan petahana di tingkat yang sama, lebih rendah, atau lebih tinggi (Kabupaten ke Provinsi) berdasarkan hubungan perkawinan, garis keturunan vertical, atau keluarga besar (Kenawas, 2015).

Berdasarkan beberapa pandangan pakar di atas, terlihat bahwa sebab-sebab politik dinasti dari perspektif hegemoni atau dominasi elit, adalah sebagai berikut: 1. Petahana atau elit yang sempat menjabat sebelumnya sebagai kelas elit (governing elite) memiliki peluang yang lebih besar mendominasi proses pemilihan umum atau pemilihan kepala daerah sehingga politik dinasti menjadi sulit dihindari; 2. Patahana atau elit yang sempat menjabat sebelumnya sebagai kelas elit menjalankan semua fungsi politik, memonopoli kekuasaan, dan menikmati keuntungan yang diberikan oleh kekuasaan; 3. Masyarakat pemilih (non-governing elite) diatur dan dikendalikan oleh kelas elit.

Penjelasan diatas kemudian menginspirasi artikel ini dengan melihat fenomena politik dinasti pada pemilihan Bupati di Kabupaten Batang Hari pada Pilkada Serentak Tahun 2020 (Lihat Tabel 1). KPU Kabupaten Batang Hari kemudian telah menetapkan tiga pasangan calon bupati dan wakil bupati. Pasangan nomor urut 1 yakni Yunninta Asmara dan M. Mahdan. Keduanya merupakan anggota aktif DPRD Kabupaten Batang Hari periode 2019-2024. Yunninta Asmara menjabat sebagai wakil ketua 1 sekaligus istri Bupati Batang Hari aktif dua periode yakni Syahirsyah. Mahdan tergabung dalam komisi 1 dari fraksi PAN dan juga pada periode sebelumnya pernah menjabat sebagai ketua DPRD Kabupaten Batang Hari. Mahdan juga merupakan adik ipar wakil Bupati Batang Hari periode 2013-2016, Sinwan yang berpasangan 
license

dengan Abdul Fattah. Mahdan juga pernah terpilih sebagai Pengganti Antar Waktu (PAW) Sinwan di DPRD Batang Hari (Tribun, 2013)

Kemudian Pasangan nomor urut 2 yakni Firdaus Fattah dan Camelia Puji Astuti. Firdaus sebelumnya menggantikan Hafiz yang gagal mencalonkan diri sebagai bupati (Ekspres, 2020). Namun keduanya merupakan putra dari mantan Bupati Batang Hari dua periode yakni Abdul Fattah (2001-2013). Sama halnya dengan Firdaus, Camelia juga merupakan Putri mantan Bupati Batang Hari periode 1980-1991 dan Wakil Gubernur Jambi periode 1994-2004, Hasip Kalimuddin Syam. Camelia juga tercatat sebagai anggota DPRD Batang Hari aktif Periode 20192024 Dari fraksi Demokrat. Pasangan nomor urut 3 yakni Muhammad Fadhil Arief dan Muhammad Bakhtiar. Keduanya memiliki latar belakang birokrat dengan jabatan sekretaris daerah (Sekda). Fadhil Arief menjabat sebagai Sekda Kabupaten Muaro Jambi dan Bakhtiar menjabat sebagai Sekda Aktif Kabupaten Batang Hari. Fadhil Arief dan Bakhtiar ini merupakan satu-satunya pasangan calon yang dianggap bebas dari politik dinasti.

Tabel 1. Latar Belakang Politik Dinasti Tiga Pasangan Calon Bupati dan Wakil Bupati Kabupaten Batang Hari Pada Pilkada Serentak Tahun 2020

\begin{tabular}{|l|l|l|}
\hline \multicolumn{1}{|c|}{ Nama } & \multicolumn{1}{|c|}{ Status Keluarga } & \multicolumn{1}{c|}{ Jabatan Politik } \\
\hline Yunninta Asmara & - Istri Syahirsyah (Bupati Batang Hari & - Wakil ketua DPRD Batang Hari \\
& Periode 2006-2011 dan 2016-2021) & \multicolumn{1}{c|}{$(2009-2014$ 2014-2019, 2019-2024) } \\
& & - Ketua DPC Partai Bintang Reformasi \\
& & - Ketua Harian Partai Golkar \\
& & \multicolumn{1}{|c|}{ Batang Hari 2014 } \\
& & - Calon Bupati Batang Hari (2020- \\
2025)
\end{tabular}




\begin{tabular}{|l|l|l|}
\hline & & $(2020-2025)$ \\
\hline Fadhil Arief & - Cucu Ulama Besar Batang Hari & - Camat Maro Sebo Ilir \\
& Jambi Haji Syukur & - Sekretaris dinas Perkebunan Batang \\
& & Hari \\
& & - Kepala Dinas Pendapatan Daerah \\
& Batang Hari \\
& & - Kepala Dinas PMD Batang Hari \\
& & - Plt Sekda Batang Hari \\
& & - Sekda Muaro Jambi \\
& - Calon Bupati Batang Hari (2020- \\
& 2025) \\
\hline Bakhtiar & - & - Sekda Batang Hari \\
& & - Calon Wakil Bupati Batang Hari \\
& & (2020-2025) \\
\hline
\end{tabular}

Sumber : diolah dari berbagai sumber

Setidaknya terdapat beberapa alasan dalam mengkaji politik dinasti pada pilkada Kabupaten Batang Hari. Pertama, Kabupaten Batang Hari telah lama didominasi oleh dua orang tokoh elit politik lama yang menjadi tonggak terbentuknya politik dinasti, keduanya ialah Abdul Fattah dan Syahirsyah. Batang Hari kemudian perlahan menjadi daerah lazim politik dinasti oleh Abdul Fattah dan Syahirsah, selain suksesi jabatan eksekutif setelah menjadi Bupati dua periode pada masanya, selama itu juga mereka telah memiliki variasi perluasan kekuasaan oleh keluarga dinasti dimana setidaknya hingga sampai saat ini anggota keluarga (anak, menantu dan istri) dua orang mantan Bupati menduduki jabatan politik hingga jabatan legislatif. Keadaan ini kemudian sesuai sebagaimana konsepsi Timothy Besley dan Marta Reynal Querol mengenai politik dinasti yakni apabila seorang pemimpin tersebut memiliki koneksi dengan keluarga yang pernah memegang posisi politik apapun, dalam kajian ini hanya mencakup istri, anak, dan menantu (Besley \& Reynal-Querol, 2013).

Kedua, terdapat upaya ingin kembali membangun dan memperluas dinasti politik melalui representasi politik mereka. Dalam tradisi politik dinasti, anggota keluarga yang sudah pernah menjadi penguasa atau menduduki jabatan publik pada umumnya akan melakukan praktik nepotisme dengan memberikan berbagai perlakuan istimewa kepada anggota keluarga atau kerabatnya, bukan untuk mensejahterakan rakyat dan memajukan daerahnya, melainkan dalam rangka membangun dan memperkuat jejaring kekuasannya. Dari sinilah kemudian embrio dinasti politik itu muncul (Sutisna, 2017). Dalam kajian ini terdapat upaya konstruksi dinasti politik lama dengan tujuan memperluas dinasti melalui pilkada Batang Hari 2020 dengan pola kekerabatan politik dengan berkolaborasi bersama keluarga elit politik lainnya dimana pasangan calon Yuninta Asmara (istri Syahirsyah) berkolaborasi dengan Mahdan (Sinwan) dan pasangan calon Firdaus Fattah (anak Abdul Fattah) dengan Camelia Puji Astuti (anak Hasip Kalimuddin Syam). Ketiga, kondisi kultural serta sikap politik masyarakat Kabupaten Batang Hari.

Literatur terdahulu telah banyak membahas mengenai awal mula munculnya politik dinasti. Asako dan McCoy dalam Winda Rosalina yang menganalisis tumbuhnya politik dinasti disebabkan karena adanya kolusi bisnis-politik ditingkat lokal. Dalam hal ini, jejaring keluarga telah menguasai berbagai proyek pembangunan daerah yang kemudian dibagi-bagikan kepada 
license

kroni-kroninya. Politik dinasti berperan sebagai patron dalam menjaga stabilitas kolusi tersebut dengan menempatkan sanak-familinya ke dalam jajaran perusahaan maupun pemerintahan. Konsep seperti ini kemudian yang menjadi awal mula terbentuknya raja-raja kecil dan mempertajam iklim kekerabatan Politik kedaerahan (Effendi, 2018).

Kemudian Winda Roselina Effendi Mencatat politik dinasti di Banten sebelum menempatkan Ratu Atut sebagai Gubernur dua periode, semuanya diawali dari faktor sejarah dan ekonomi politik dimana elit politik Chasan Sochib yang merupakan pengusaha biasa kemudian menjalin hubungan erat dengan perwira militer dan petinggi Golkar Banten yang dulunya merupakan penguasa lokal Banten. Pasca keruntuhan orde baru, Chasan Scohib juga merupakan aktor utama terbentuknya Provinsi Banten (Effendi, 2018).

Senada dengan Winda, Penelitian Suaib dan Zuada yang membahas bagaimana hegemoni politik Nur Alam (Gubernur Sultra dua Periode) di Sulawesi Tenggara yang kemudian membentuk sebuah dinasti politik. Sosok Nur Alam yang menjelma menjadi "bos lokal" sebelum menjadi politisi dan membentuk sebuah politik dinasti, ia sebelumnya merupakan seorang pengusaha yang merintis pekerjaannya sejak zaman orde baru dan menjadikannya sebagai ketua Gapensi dan Kadinda Sultra yang memuluskan karir politik Nur Alam semakin melejit. Sebagai ketua DPW PAN ia memiliki pengaruh dan mendukung kakak kandungnya sebagai calon bupati konawe periode 2015-2020 dan mempersiapkan istrinya Asnawati Hasan untuk Maju sebagai Gubernur Sultra 2018 (Suaib \& Zuada, 2015).

Kedua literatur di atas menjelaskan munculnya politik dinasti karena faktor sejarah dan ekonomi politik yang dibentuk oleh individu yang menguasai sektor ekonomi dan berpengaruh di berbagai bidang di wilayah tersebut. Kealpaan dari penelitian di atas adalah tidak membahas munculnya politik dinasti (selain karena faktor ekonomi politik dan sejarah), bahwa setidaknya iklim dinasti Politik juga disebabkan melalui faktor cultural, dalam hal ini adalah masyarakat yang cenderung masih tradisional. Kemudian dalam konteks Kabupaten Batang Hari, politik dinasti itu muncul dan langgeng bukan hanya karena strategi politik disaat pencalonan, kampanye sebagai moda memperoleh kemenangan, akan tetapi juga karena keadaan ekonomi dan Pendidikan masyarakat Kabupaten Batang Hari yang cukup rendah sehingga memaksa mereka untuk mengabaikan sisi objektifitas pasangan calon dan cenderung lebih pragmatis.

\section{Metode}

Guna memahami kontestasi kekuasaan di Batang Hari, penelitian kualitatif deskriptif ini mengandalkan kombinasi informasi sekunder dari berbagai sumber dan data primer dari hasil observasi, wawancara terhadap informan untuk memahami secara dalam mengapa faktor cultural masyarakat yang menjadi penyebab munculnya kekerabatan Politik di Batang Hari. Penggalian informasi menggunakan kuesioner terbuka semi terstruktur dalam sejumlah kecil kasus untuk mengungkap fakta tentang fenomena yang ada (Joubish, M. F., Khurram, M. A., Ahmed, A., Fatima, S. T., 2011).

Penentuan informan berdasarkan pemahaman terhadap data yang diperlukan yang diambil dari berbagai level lapisan infrastuktur politik (Kecamatan dan Desa), berbagai kalangan serta pemangku kepentingan di level masyarakat. Berbagai level tersebut hanya diambil beberapa perwakilan yang dianggap memiliki kemampuan dalam memberikan informasi yang objektif. Penggunaan metode ini dianggap tepat, karena dianggap mampu menjawab munculnya 
license

fenomena konstruksi politik dinasti pada pemilihan Bupati Batang Hari 2020 dalam perspektif kedaerahan.

Berbagai data primer dan sekunder digunakan untuk memahami gejala-gejala atas fenomena yang terjadi. Analisis data dilakukan dengan menggunakan interactive model analysis, dimana pada tahap awal dilakukan proses koding yang tersistematis untuk menemukan konsep, kategori serta membuktikan hipotesa awal (Miles, H., \& Huberman, 2014). Kemudian dilakukan analisis membandingkan dengan temuan penelitian terdahulu untuk menunjukkan kebaruan atau mengkonfirmasi teori yang ada. Disamping itu, dilakukan konfirmasi keabsahan data secara berulang melalui penelusuran informasi dengan cermat.

\section{Hasil dan Pembahasan}

Kabupaten Batang Hari sejak era reformasi hingga saat ini telah mengalami dinamika kontestasi politik pemilihan kepala daerah yang kemudian menarik untuk di kaji. Era desentralisasi justru memperkuat kekuatan politik lama untuk kembali. Kekuatan reformasi mengalami demobilisasi dan domestikasi. Tidak ada perbedaan gagasan yang substantif ditawarkan elit-elit lama yang bertarung di era desentralisasi (Hutabarat, 2012). Dinamika tersebut memunculkan fenomena dimana kekuasaan politik di Kabupaten Batang Hari dijalankan oleh dua orang tokoh yang memimpin dan mendominasi pemerintahan daerah Batang Hari sejak tahun 2001 hingga tahun 2020, yakni H. Abdul Fattah dan Ir. Syahirsah, Sy. Meskipun Sinwan sempat menjadi Bupati Batang Hari 2013-2016 menggantikan posisi Fattah pada saat ditengah kepemimpinannya harus divonis bersalah atas kasus korupsi pengadaan mobil pemadam kebakaran Pemerintah kabupaten Batang Hari tahun 2004 (Tempo, 2014).

Tabel 2. Daftar Bupati dan Wakil Bupati Batang Hari (2001-2021)

\begin{tabular}{|c|c|c|}
\hline Bupati & Wakil Bupati & Periode \\
\hline H. Abdul Fattah & Ir. Syahirsah, Sy & $2001-2006$ \\
\hline Ir. Syahirsah, Sy & H. Ardian Faisal & $2006-2011$ \\
\hline H. Abdul Fattah & Sinwan S.H & $2011-2013$ \\
\hline Sinwan S.H & - & $2013-2016$ \\
\hline Ir. Syahirsah, Sy & Hj. Sofia Joesoef S.H & $2016-2021$ \\
\hline
\end{tabular}

Sumber. Situs Pemerintah Kabupaten Batang Hari (Diskominfo, 2012)

Pada Awal kepemimpinan Fattah dan Syahirsah di tahun 2001, beberapa tahun setelah krisis ekonomi 1998, Batang Hari dihadapkan dengan permasalahan kemiskinan. Batang Hari menjadi Kabupaten dengan jumlah penduduk miskin terbanyak kedua di Provinsi Jambi dengan persentase 19,10\% dengan pendapatan perkapita masyarakat Batang Hari Sebesar Rp. 3.686.618 (BPS, 2002). Kekuasaan mereka gagal meningkatkan kesejahteraan rakyat karena jika dilihat dari persentase jumlah penduduk miskin di Batang Hari tidak mengalami perubahan yang terlalu signifikan dalam kurun waktu empat tahun kepemimpinan mereka. 
Pada pilkada berikutnya tahun 2005 keduanya memutuskan berpisah dan saling bertarung untuk kembali mencalonkan diri sebagai Bupati dan Wakil Bupati dengan pasangan baru. Syahirsah keluar sebagai pemenang bersama Ardian Faisal yang merupakan putra dari Saman Chatib Bupati Batang Hari Periode 1991-2001 mengalahkan Abdul Fattah yang berpasangan dengan Ali Redo.

Pada masa kepemimpinannya Syahirsah dan Ardian Faisal belum mampu mewujudkan kesejahteraan masyarakatnya dengan dilihat dari banyaknya jumlah pengangguran di Batang Hari dan menjadi yang terbanyak ketiga di Provinsi Jambi. Sebanyak 9.057 penduduk Batang Hari belum mendapat pekerjaan atau menganggur dijumlahkan berdasarkan pendidikan yang ditamatkan (BPS, 2007). Jika dilihat dari laju pertumbuhan pendapatan perkapita selama tahun 2005-2009, Kabupaten Batang Hari menempati urutan ke delapan dari 10 kabupaten/kota di provinsi Jambi. Selama tahun 2005 - 2009 pertumbuhan perkapita tertinggi terjadi pada tahun 2005 dan terendah terjadi pada tahun 2006 sebesar 2.92 persen dari tahun sebelumnya (Nurhayani, 2011).

Berlanjut Pada pilkada 2010, Syahirsah dan Abdul Fattah kembali mencalonkan diri sebagai Bupati dan Wakil Bupati Batang Hari untuk periode 2011-2016. Pilkada di ikuti 5 pasangan calon yakni, Syahirsah-Erpan, Abdul Fattah-Sinwan, Hamdi Rachman-Juhartono, Ardian Faisal-Apani. Abdul Fattah keluar sebagai pemenang dan terpilih kembali sebagai Bupati Batang Hari untuk Periode keduanya (2011-2016) mengalahkan Incumbent Syahirsyah dengan jumlah perolehan suara terbanyak kedua.

Pasca ditetapkan sebagai Bupati terpilih, masa jabatan Abdul Fattah tidak berlangsung lama setelah dirinya di tetapkan sebagai tersangka dan dinyatakan terbukti bersalah melakukan tindak pidana korupsi pengadaan mobil pemadam kebakaran sebesar Rp 1,1 miliar pada 2004 oleh majelis hakim Pengadilan Tindak Pidana Korupsi (Tipikor) Jambi di Pengadilan Negeri Jambi, Selasa, 26 November 2013. Abdul Fattah dijatuhi vonis hukuman 14 bulan penjara subsider dua bulan kurungan dan denda Rp 50 juta (Tempo, 2013). Abdul Fattah kemudian digantikan oleh Sinwan.

Jika dilihat dari Visi dan Misi yang di tawarkan oleh Fattah bersama Sinwan, Ekonomi Rakyat menjadi hal yang utama. Namun faktanya hal tersebut kembali gagal terwujud dalam rentang waktu 2011-2016 masa jabatan, terjadi peningkatan persentase penduduk miskin di Kabupaten Batang Hari dan menjadi yang terburuk ketiga dari 11 Kabupaten/kota di Provinsi Jambi. Tahun 2011-2013 persentase penduduk miskin Batang Hari sebesar 9,56\% - 10,42\%, Sedangkan tahun 2014-2016 sebesar 10,50\% - 10,79\% (BPS, 2011, 2014). Setelah habis dua periode masa jabatan, Abdul Fattah kemudian mendampingkan istrinya Sofia Joesoep sebagai wakil Syahirsah pada Pilkada Tahun 2015.

Setelah secara resmi terpilih, Syahirsah telah memasuki periode keduanya dalam memimpin Kabupaten Batang Hari. Banyak masyarakat yang menaruh kembali harapan besar kepada Syahirsyah setelah di masa kepemimpinannya (2006-2011) serta kepemimpinan bupati sebelumnya (2011-2015) terbukti belum mampu menyelesaikan masalah yang selama ini dirasakan oleh masyarakat yakni kemiskinan yang lagi-lagi tidak terjadi mengalami perubahan yang signifikan, ketimpangan pembangunan, lapangan pekerjaan dan lain-lain sehingga pada pada akhirnya seperti Survey Public Trust Institute (Putin) terbaru menunjukan sebanyak 53\% masyarakat Batang Hari tidak puas dengan kepemimpinan Syahirsah (Putin, 2020). 
Keadaan sosial ekonomi masyarakat yang memprihatinkan selama kurang lebih 20 tahun secara tidak langsung mendukung kelanggengan pelokalan politik. Dalam kondisi ini para calon yang akan bertarung pada pilkada Batang Hari 2020 memanfaatkannya sebagai alat untuk mendulang suara. Jika dilihat dari latar belakang pekerjaan masyarakat Batang Hari yang rata-rata bekerja sebagai petani atau peternak dengan rata-rata penghasilan yang cukup rendah dibandingkan dengan Upah Minimum Regional (UMR) dan pendidikan mayoritas tamatan SLTA, hal-hal yang berkaitan dengan objektifitas (pendekatan Rasional) terkait pasangan calon yang akan memimpin daerahnya cenderung teralihkan. Masyarakat Batang Hari cenderung menyukai hal-hal praktis yang akan didapat sesuai kebutuhan mereka seperti mahar politik atau politik uang. Mayoritas 67\% masyarakat Batang Hari menerima (dengan pertimbangan) adanya pemberian mahar politik atau politik uang pada pemilihan Bupati dan Wakil Bupati dan 33\% tidak menerima karena tidak setuju dengan politik uang (Putin, 2020).

Gambar 1. Data Jenis Pekerjaan Masyarakat Batang Hari

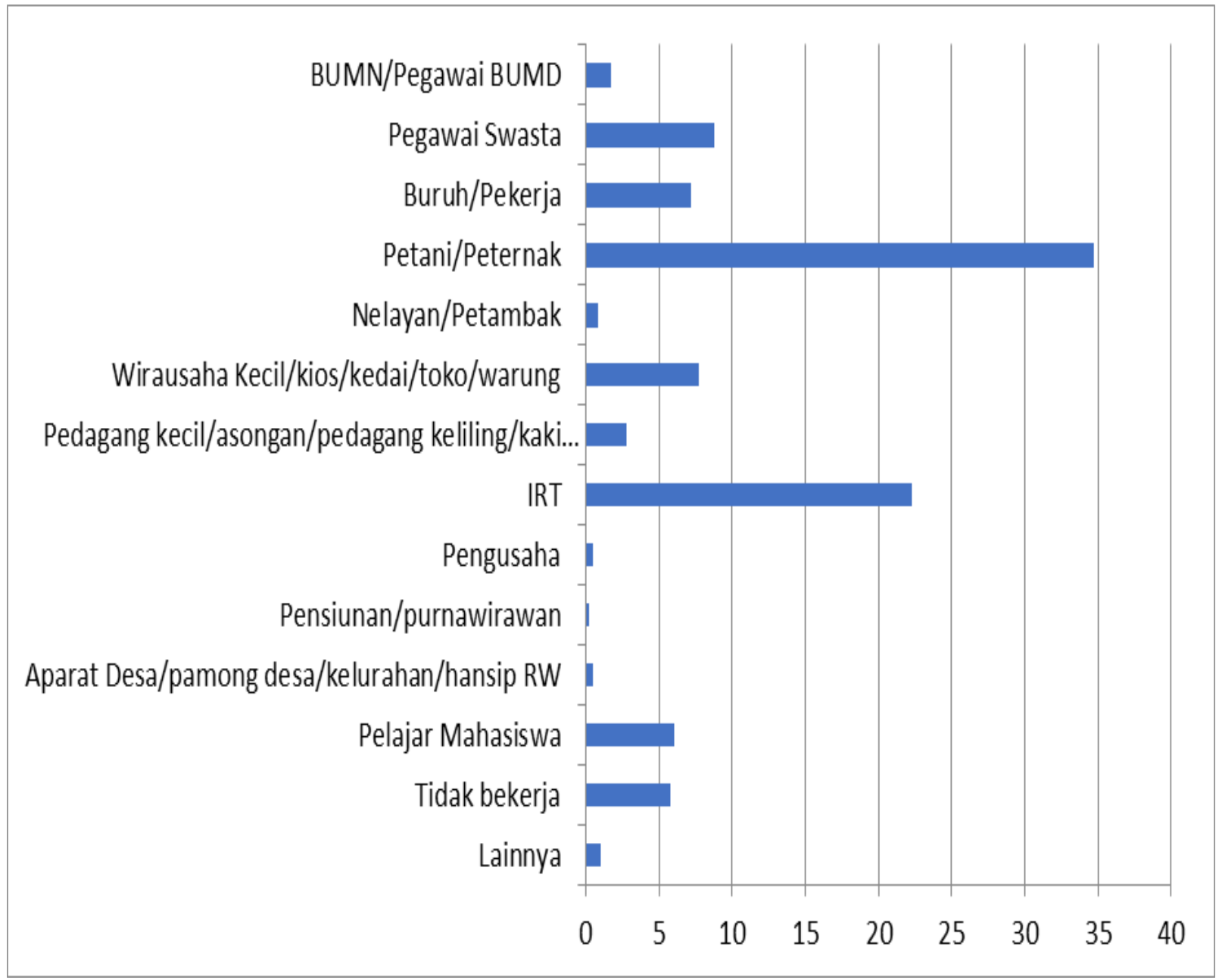

Sumber: Public Trus Institute (Putin) (Putin, 2020) 
Gambar 2. Data Rata-rata Pendapatan Masyarakat Batang Hari

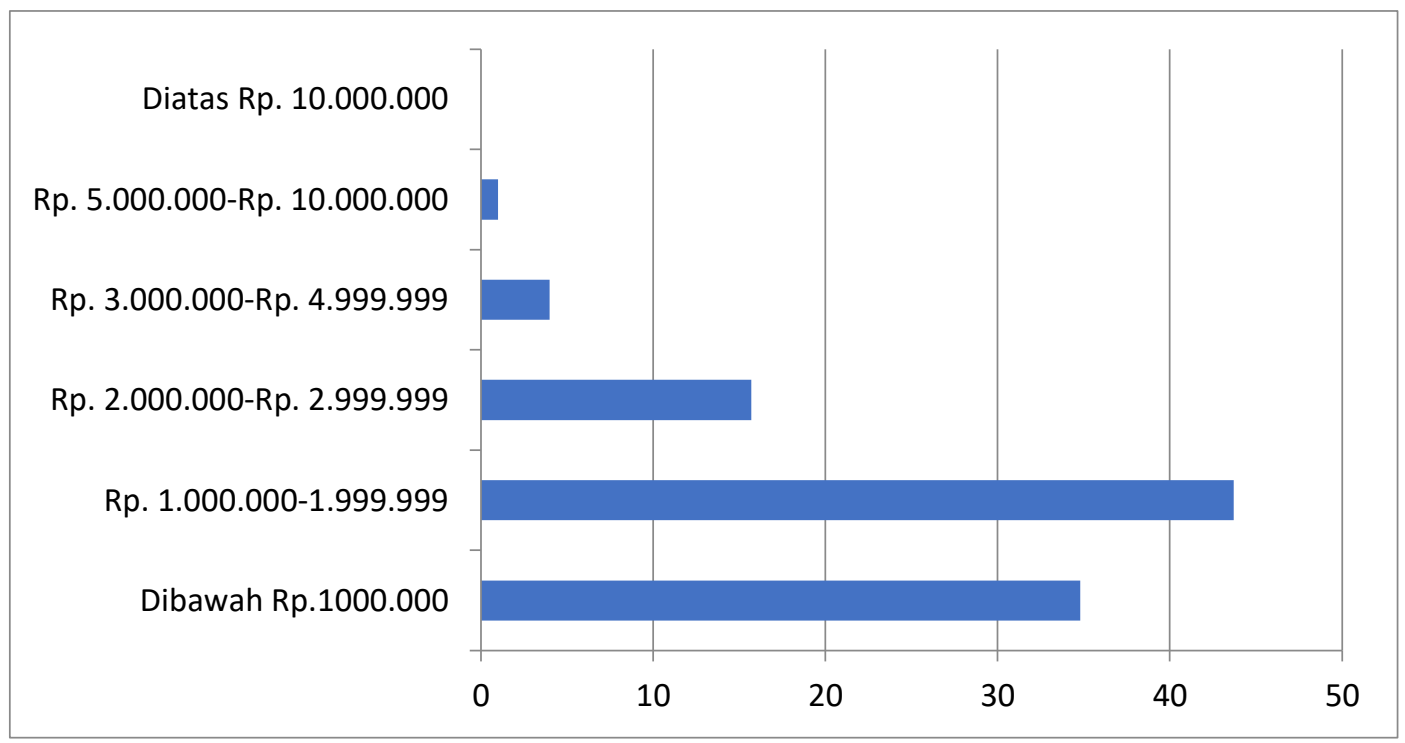

Sumber: Public Trus Institute (Putin) (Putin, 2020)

Gambar 3. Data Persepsi Masyarakat Batang Hari mengenai Politik Uang

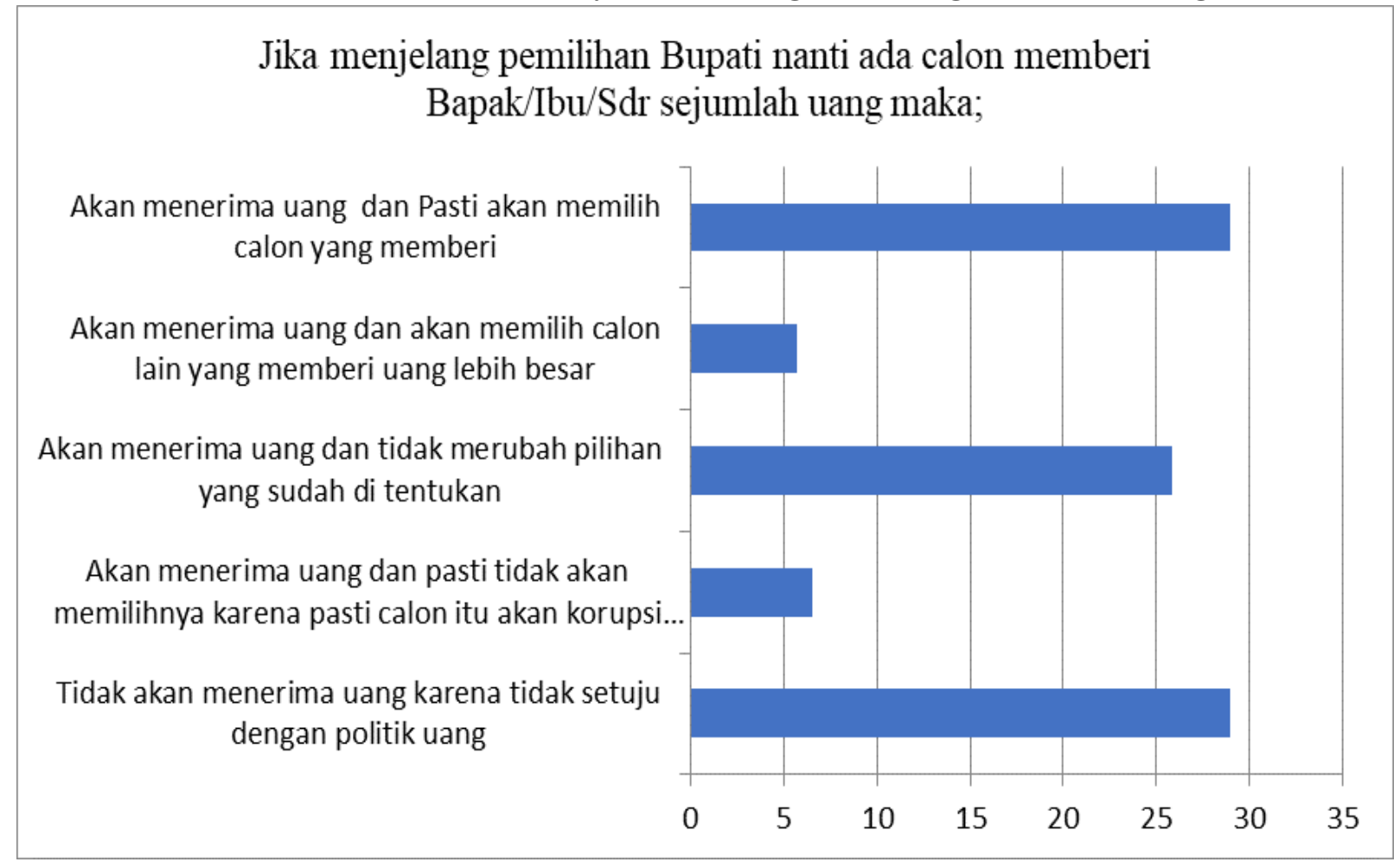

Sumber: Public Trust Institute (Putin) (Putin, 2020)

Berdasarkan penjelasan diatas dapat disimpulkan bahwa Pertama, dari fenomena kepemimpinan selama hampir 20 tahun oleh dua orang tokoh yang sama, tidak terjadi perubahan secara signifikan akan tetapi masyarakat masih terus menerima untuk memilih salah salah satu diantara mereka ketika masa pemilihan Bupati dilaksanakan. Kedua, sebagaimana yang dijelaskan diawal, masyarakat setempat yang merawat politik dinasti di Batang Hari sehingga tumbuh dan 
license

berkembang hingga saat ini dan juga dilihat dari culture masyarakat telah membentuk perilaku memilih masyarakat yang notabene cenderung masih tradisional. Ketiga, Persoalan ekonomi masyarakat harus menjadi perhatian utama untuk ditingkatkan diiringi dengan kualitas pendidikan formal maupun pendidikan politik kepada seluruh lapisan masyarakat.

Pewarisan kekuasaan dan perluasan basis kekuasaan untuk jabatan terpilih melalui mekanisme demokrasi sangat dimungkinkan dengan mengandalkan nama keluarga, serta jejaring kekuasaan politik untuk memenangkan sebuah pemilihan. Kemampuan keluarga dinasti untuk membangun dan memperkuat jaringan keluarganya, mengumpulkan kekayaan, dan akhirnya menciptakan ketidakmerataan lapangan bermain (proses elektoral), sangat penting dalam menentukan keberhasilannya dalam membangun dinasti politik (Kenawas, 2015).

Realitas yang telah dipaparkan sebelumnya membuat penulis berargumen bahwa Pilkada Batang Hari 2020 secara tidak langsung kembali menjadi ajang pertarungan dua tokoh dinasti (Abdul Fattah dan Syahirsah) melalui representasi masing-masing dari mereka (Lihat Tabel 1) dengan pola kekerabatan politik dan terdapat upaya membangun dan memperluas dinasti politik di Batang Hari. Sebenarnya, pada pilkada Batang Hari 2020 terdapat tiga pasang calon yang berkontestasi. Hal ini secara prosedural tidak menjadi masalah karena terdapat peluang bagi semua pihak untuk berkompetisi, dan di satu sisi memberi kesempatan rakyat untuk memilih kandidat yang diinginkannya. Akan tetapi, terlihat jelas bahwa sirkulasi elit lokal tidak berjalan secara maksimal karena kursi kepemimpinan hanya berputar pada dua tokoh lama.

Selanjutnya, Berbagai uraian di atas menunjukkan adanya dimensi rasionalitas yang cenderung berbicara pada sisi negative soal pragmatisme untung dan rugi yang didapatkan secara praktis sehingga melupakan apa yang sebenarnya menjadi poin-poin rasionalitas (visi misi, program kerja, pembangunan) yang berperan dalam membentuk perilaku memilih masyarakat Batang Hari.

\footnotetext{
Masyarakat akan lebih memilih kandidat yang memberikan uang sehingga kedatangan mereka ke tempat pemilihan suara (TPS) dengan meninggalkan pekerjaan tidak sia-sia. Mereka beranggapan bahwa biasanya butuh waktu kurang lebih dua minggu penuh untuk menikmati hasil panen lalu ketika diberi uang banyak dalam satu hari hanya untuk memilih, mereka bersedia untuk libur bertani. Hal tersebut di dorong juga oleh kelemahan dalam hal perekonomian dan pendidikan masyarakat (Wawancara dengan Mansur, 27 September 2020 (Lihat Gambar 1-2).
}

Studi oleh Camp di Meksiko dan Mendoza dalam catatan Yoes C. Kenawas tentang politik dinasti Filipina menunjukkan bahwa kebangkitan politik dinasti dapat dikaitkan sebagian kepada masyarakat tradisional dan kondisi ekonomi yang memprihatinkan dimana pemilih dengan ekonomi rendah status cenderung memilih politisi dinasti (Kenawas, 2015).

Dalam konteks dinamika politik dinasti Batang Hari, Konsepsi Pendekatan Rasional yang cenderung berbanding terbalik dan mengarah kepada persoalan untung dan rugi soal materi secara praktis dengan pendekatan rasional pada umumnya yang menurut Mas'udi, Qodarsasi, \& Dewi, 2018 soal perilaku memilih dimana yang dipertimbangkan adalah orientasi visi misi, prestasi kandidat, kedudukan informasi dan popularitas pribadi kandidat, kedudukan informasi 
license

dan popularitas pribadi. Masyarakat dengan mayoritas latar belakang pekerjaan adalah petani atau peternak misalnya cenderung pragmatis dan tidak memperhatikan poin-poin utama pendekatan rasional dalam memilih (Mas'udi et al., 2018).

Fenomena ini akan memperburuk kualitas demokratisasi di Kabupaten Batang Hari, baik dari segi sirkulasi kepemimpinan maupun kesadaran partisipasi publik secara nyata dalam konteks pembangunan daerah. Masyarakat seolah tidak peduli siapa, dari kalangan mana calon pemimpin daerah mereka di masa yang akan datang. Latar belakang ekonomi yang selama ini menjadi permasalahan memaksa masyarakat untuk tidak peduli figure pasangan calon.

Kemudian mengenai konsepsi rational choice atau Pilihan rasional dimana pilihan pemilih adalah keputusan rasional pemilih dimana yang dipertimbangkan adalah orientasi visi misi, prestasi kandidat, kedudukan, informasi dan popularitas pribadi (Mas'udi et al., 2018). Pada dasarnya masyarakat Batang Hari sadar bahwa politik dinasti telah berdiri lama di daerahnya, Akan tetapi mayoritas tidak setuju dengan adanya politik dinasti di Batang Hari. Berdasarkan survey terbaru Putin (2020), sebanyak 50,7\% Masyarakat Batang Hari tidak setuju dengan adanya dinasti politik.

Gambar 4. Data Persepsi Masyarakat Batang Hari Terhadap Dinasti Politik

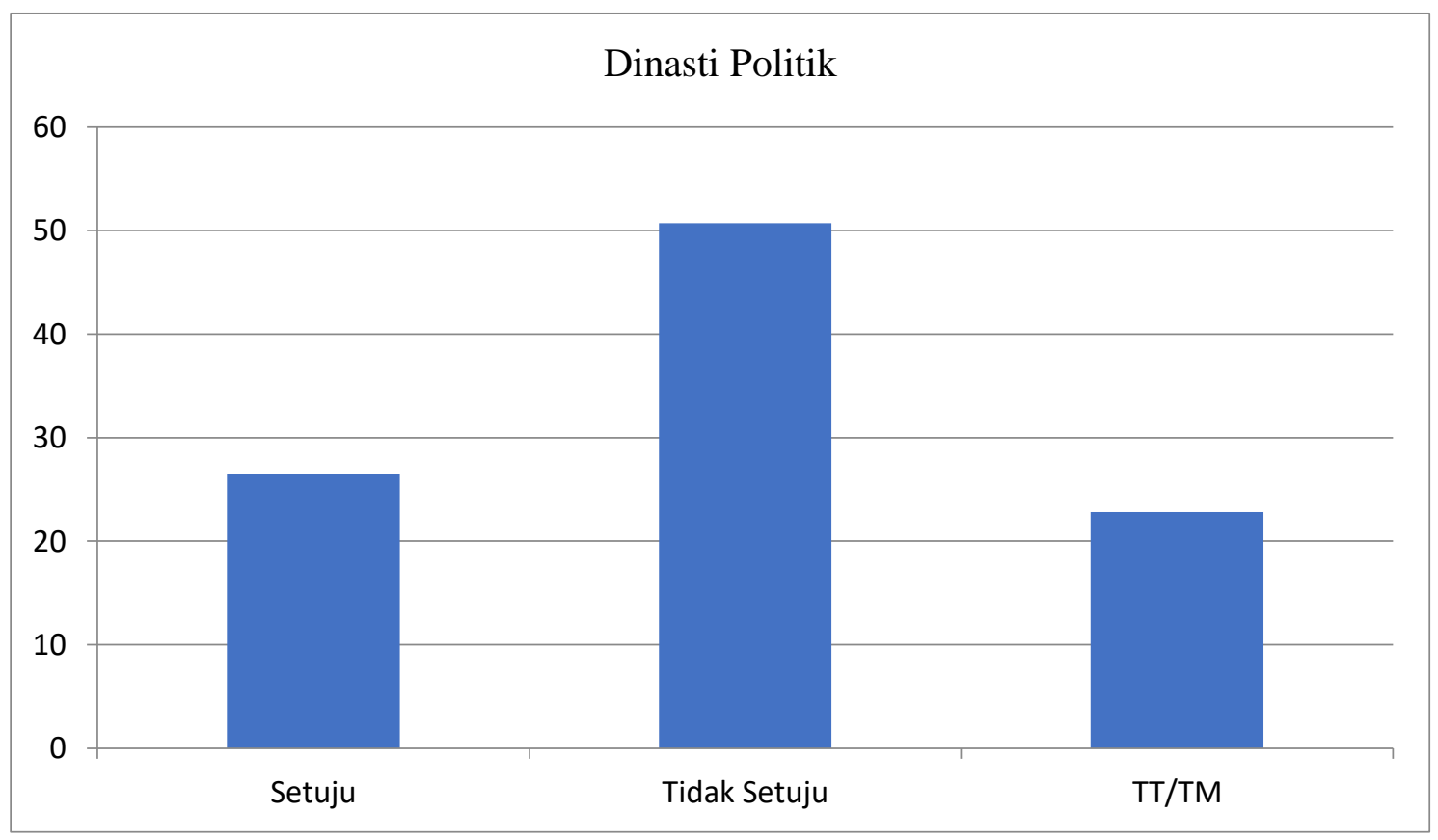

Sumber: Public Trust Institute (Putin) (Putin, 2020)

Politik dinasti melalui kekerabatan Politik mengabaikan prinsip-prinsip pemilihan umum yang adil. Para kerabat yang menggantikan posisi incumbent ataupun ingin mengambil kembali posisi lama (Bupati/Wakil Bupati) yang pernah di tempatkan oleh istri, anak, ataupun saudara sudah pasti akan mengambil manfaat, sekurang-kurangnya popularitas. Seperti misalnya pasangan Firdaus-Camelia yang menonjolkan nama 'Fattah' dan 'Hasip' dibelakang nama mereka dan tentunya tidak asing lagi di telinga masyarakat Batang Hari. Sementara nama Yuninta dan 
Mahdan dengan sendirinya telah ter-branding sebagai istri dan adik ipar Bupati Batang Hari sebelumnya.

Lebih lanjut Aninda mencatat bahwa politik dinasti dalam proses pencalonan juga bisa merusak sistem kaderisasi partai politik. Penguatan institusionalisasi politik kepartaian menjadi terhambat karena peluang kader-kader terbaik partai diambil alih para kerabat yang baik dari segi kuantitas kaderisasi maupun kualitas sebenarnya bisa saja belum memenuhi persyaratan. Firdaus yang berasal dari latar belakang seorang Dokter harus maju sebagai calon Bupati menggantikan adiknya yang merupakan ketua DPD PAN Batang Hari, Sedangkan Camelia di usung oleh partai yang ia pimpin yakni partai Demokrat. Adapun Pasangan Yuninta-Mahdan selain diusung oleh partai PDI, Gerindra dan perindo juga diusung oleh salah satu partai besutan suami Yuninta yakni partai Golkar. Jika realitas seperti ini terus berkembang dan meluas di Batang Hari, maka kedepannya Batang Hari akan mengalami kemandegan sirkulasi kepemimpinan yang memberikan kemajuan daerahnya.

\section{Kesimpulan}

Politik dinasti yang dibangun antara sesama keluarga elit politik Batang Hari yang telah mengakar lama kemudian terus berupaya untuk di perluas pada pilkada serentak di Kabupaten Batang Hari selain karena beberapa faktor yang telah dijelaskan diatas, juga disebabkan oleh kondisi sosio-culture yang merupakan buntut dari keadaan ekonomi masyarakat. Rencana pelanggengan politik dinasti menjadi salah satu implikasi yang disebabkan oleh kedua hal tersebut. Keadaan seperti ini tentu saja akan membuat aspek kapabilitas dan kualitas dalam memilih pemimpin cenderung terabaikan.

Mayarakat Batang Hari yang mayoritas secara culture masih tradisional cenderung pragmatis dalam hal menggunakan hak memilih. Pendekataan perilaku memilih model Rasionalitas sangat menggambarkan realitas masyarakat Batang Hari pada proses pergantian kepemimpinan. Hal-hal yang secara praktis menguntungkan mereka secara individu menjadi alasan untuk seseorang memilih. Perlu adanya upaya dari pemerintah setempat untuk lebih intensif dalam meningkatkan indeks pembangunan manusia baik dari segi pendapatan per kapita dan juga pendidikan masyarakat.

Selain itu, politik dinasti juga disebabkan oleh kegagalan partai politik dalam melakukan proses kaderisasi kepemimpinan. Perlu adanya perhatian khusus, desakan publik serta evaluasi pada proses rekrutmen oleh partai politik yang seharusnya sesuai dengan merit system tanpa melihat latar belakang mereka sehingga nantinya memang muncul calon pemimpin yang kompeten dalam politik sebagaimana mestinya. Kemudian juga pendidikan politik terhadap masyarakat Batang Hari harus secara massif di sosialisasikan hingga ke akar rumput kelompok masyarakat.

\section{Referensi}

Aninda, R. D. (2010). Pelanggengan Politik Dinasti "Samawi". Sebuah studi perilaku pemilih model psikologis pada pilkada Bantul 2010. Politika: Jurnal Ilmu Politik, 3(2), 15-28.

Besley, T., \& Reynal-Querol, M. (2013). Selection via Dynasties: Theory and Evidence. Working Paper.

BPS. (2002). Persentase Penduduk Miskin tahun 2002-2004. Badan Pusat Statistik Provinsi Jambi. 
BPS. (2007). Pengangguran terbuka menurut Kabupaten/Kota dan pendidikan yang ditamatkan. Badan Pusat Statistik Provinsi Jambi.

BPS. (2011). Persentase Penduduk Miskin 2011-2013. Badan Pusat Statistik Provinsi Jambi.

BPS. (2014). Persentase Penduduk Miskin tabun 2014-2016. Badan Pusat Statistik Provinsi Jambi.

CNN Indonesia. (2020). 290 Calon Petahana Maju Pilkada di 236 Daerah.

Dal Bó, E., Dal Bó, P., \& Snyder, J. (2009). Political dynasties. Review of Economic Studies, 76(1), 115-142. https://doi.org/10.1111/j.1467-937X.2008.00519.x

Diskominfo. (2012). Sejarah Singkat Kabupaten Batang Hari. Situs Pemerintah Kabupaten Batang Hari.

Effendi, W. R. (2018). Dinasti Politik Dalam Pemerintahan Lokal Studi Kasus Dinasti Kota Banten. Jurnal Trias Politika, 2(2), 233. https://doi.org/10.33373/jtp.v2i2.1471

Ekspres, J. (2020). Batal Maju di Pilbup Batang Hari, Hafiæ̧ Fattah: Saya Digantikan M Firdaus Berita Jambi Ekspres - JAMBIEKSPRES.CO.ID.

Feinstein, B. D. (2010). The dynasty advantage: Family ties in congressional elections. Legislative Studies Quarterly, 35(4), 571-598. https://doi.org/10.3162/036298010793322366

Geys, B., \& Smith, D. M. (2017). Political Dynasties in Democracies: Causes, Consequences and Remaining Puzzles. Economic Journal, 127(605), F446-F454. https://doi.org/10.1111/ecoj.12442

Hamid, A. (2015). Observation of Democratic Decentralization in Indonesia during 2009-2014: Political Dynasty in Banten Province and Populism in Jakarta Province. Doshisha University.

Hanafi, R. I. (2014). Pemilihan Langsung Kepala Daerah di Indonesia: Beberapa Catatan Kritis Untuk Partai Politik. Jurnal Penelitian Politik, 11(2), 1-16.

Hutabarat, M. P. (2012). Fenomena “Orang Kuat Lokal” Di Indonesia Era Desentralisasi (Studi Kasus Tentang Dinamika Kekuasaan Zulkifli Nurdin Di Jambi). Fisip Ui, 1-95.

Joubish, M. F., Khurram, M. A., Ahmed, A., Fatima, S. T. (2011). Paradigms and characteristics of a good qualitative research. World Applied Sciences Journal, 12(11), 2082-2087.

Kenawas, Y. C. (2015). The Rise of Political Dynasties in a Democratic Society. EDGS Working Paper-Arryman Fellow, 22, 1-58.

Mas'udi, M., Qodarsasi, U., \& Dewi, N. R. (2018). Perilaku Partisipasi Pemilih pada Pemilihan Kepala Daerah Kabupaten Kudus Tahun 2018. JSW (Jurnal Sosiologi Walisongo), 2(2), 169_ 188. https://doi.org/10.21580/jsw.2018.2.2.3038

Miles, H., \& Huberman, A. M. S. (2014). Qualitative data analysis: A methods sourcebook. A methods sourcebook.

Nurhayani. (2011). Analisis Pendapatan dan Pengeluaran Perkapita di Kabupaten. Jurnal Paradigma Ekonomika, 1(4), 48-61.

Prianto, B. (2016). Partai Politik, Fenomena Dinasti Politik Dalam Pemilihan Kepala Daerah, Dan Desentralisasi. Publisia: Jurnal Ilmu Administrasi Publik, $1(2)$. https://doi.org/10.26905/pjiap.v1i2.436

Putin. (2020). Perilaku memilih dalam menghadapi pemilihan Bupati dan Wakil Bupati Batang Hari 2020.

Querubin, P. (2013). Dynasties in the Philippines *. In APS A 2012 Annual Meeting Paper.

Suaib, E., \& Zuada, L. H. (2015). Fenomena 'Bosisme Lokal' Di Era Desentralisasi: Studi Hegemoni Politik Nur Alam Di Sulawesi Tenggara. Jurnal Penelitian Politik, 12(2), 51-69.

Sutisna, A. (2017). Gejala Proliferasi Dinasti Politik di Banten Era Kepemimpinan Gubernur 
Copyright (C) 2021, Hatta Abdi Muhammad, Dony Anggara

This is an open access article under the CC-BY-SA license
ISSN 2088-8090 (Print) ISSN 2597-6648 (Online) Sospol: Jurnal Sosial Politik Vol 7 No 2 (2021), pp.161-175

Ratu Atut Chosiyah. Politik Indonesia: Indonesian Political Science Review, 2(2), 100. https://doi.org/10.15294/jpi.v2i2.9329

Tempo. (2014). Korupsi, Bupati Batang Hari Divonis 14 Bulan Bui.

Tribun, J. (2013). Pengganti Sinwan Dilantike Akbir Maret - Tribun Jambi.

\section{Wawancara}

Mansur (2020). Batang Hari, 27 September 2020 